\title{
Patient screening for cardiac hemochromatosis, echocardiography or MRI?
}

\author{
L.H.B. Baur
}

Published online: 16 December 2008

(C) The Author(s) 2008. This article is published with open access at Springerlink.com

Hereditary hemochromatosis is autosomal recessive disorder associated with the HLA-A locus on the short arm of chromosome 6 [1]. Excessive iron deposition occurs mostly in the heart, pancreas and pituitary. In normal subjects, absorption of iron from the gut is inversely correlated with iron stores. In homozygous hereditary hemochromatosis there is increased absorption of iron, which is not regulated by iron stores [2]. This leads to progressive iron accumulation because there is no normal mechanism for excretion of excess iron once it has been absorbed into the body. The clinical manifestations of iron overload include liver disease in $75 \%$ of cases, weakness and lethargy in $74 \%$, skin hyperpigmentation in $70 \%$, diabetes mellitus in $48 \%$, arthralgia in $44 \%$, impotence in $45 \%$, electrocardiographic abnormalities in $31 \%$ and heart failure and conduction disturbances in $15 \%[3,4]$. Repeated phlebotomy can prevent iron accumulation in the heart. At this moment T2* magnetic resonance imaging is the best way for early detection of iron overload in patients with hemochromatosis $[5,6]$. However, magnetic resonance imaging is time

Editorial comment to the paper entitled "Left ventricular longaxis function in treated haemochromatosis" by Davidsen et al. Doi: $10.1007 / \mathrm{s} 10554-008-9383-4$.

\section{L.H.B.Baur $(\square)$}

Department of Cardiology, Atrium Medical Centre

Parkstad, University of Maastricht, 5, Henri Dunant street, 6401 Maastricht, CX Heerlen, The Netherlands

e-mail:1br01@atriummc.nl consuming and expensive. If echocardiography would be able to detect cardiac iron overload in the same way as $\mathrm{T} 2 *$ magnetic resonance imaging, this would be more cost effective and could be used to screen patients with hemochromatosis on the presence or abscense of cardiac involvement. The study of Davidsen et al. in the current issue of the International Journal of Cardiac Imaging shows, that tissue Doppler imaging was able to detect hemochromatosis determination of $S^{\prime}[7]$. A cut-off value of $S^{\prime}=10.88 \mathrm{~cm} / \mathrm{s}$ achieved a $56 \%$ sensitivity and $74 \%$ specificity for separating haemochromatosis from controls (Communication from the authors). This gives a positive predictive value of $68 \%$ and a negative predictive value of $57 \%$. Although the discriminating value of $S^{\prime}$ is not extremely high, echocardiography with tissue Doppler imaging could be used as a screening tool to detect cardiac involvement in patients with haemochromatosis. One has to be aware that the negative predictive value is slightly higher than $50 \%$. This means, that if no abnormalities can be found, additional imaging with T2* MRI is still needed. At this moment echocardiography and tissue Doppler imaging is not able to replace T2* magnetic resonsance imaging. Even if echocardiographic abnormalities are found it will be prudent to perform additional imaging with T2* MRI.

However, because echocardiography and tissue Doppler imaging is a cheap, non-invasive and easy technique initial screening in patients with haemochromatosis can be done using this technique followed 
by magnetic resonance imaging. If the diagnosis of cardiac haemochromatosis is established, both echocardiography and T2* MRI could be used for followup guidance of left ventricular function after therapeutic phlebotomy and chelation therapy [8]. In this situation, estimation of iron stores in the heart would be very helpful in order to evaluate the efficacy of chelation therapy and determine the cardiac risk. Although the iron storage proteins like hemosiderin and ferritin are mostly intracellular, serum ferritin is highly correlated with the amount of iron deposition and can therefore used as an index for intracardiac iron load [9]. However, ferritin levels can be affected by factors as fever or inflammation [10]. T2 relaxation time has a linear correlation with the total iron content in the heart [11]. Echocardiography with tissue velocity imaging is able to detect early ventricular function and ventricular dilation in thallassemia patients, but it does not detect cardiac iron load [12].

Therefore cardiac magnetic resonance imaging remains the preferred technique to image iron load in the myocardium in patients with haemochromatosis and guide chelation therapy.

Open Access This article is distributed under the terms of the Creative Commons Attribution Noncommercial License which permits any noncommercial use, distribution, and reproduction in any medium, provided the original author(s) and source are credited.

\section{References}

1. Schrier SL, Bacon BR (2008) Clinical manifestations of hereditary chromatosis
2. Lynch SR, Skikne BS, Cook JD (1989) Food iron absorption in idiopathic hemochromatosis. Blood 74:21872193

3. Niederau C, Strohmeyer G, Stremmel W (1994) Epidemiology clinical spectrum and prognosis of hemochromatosis. Adv Exp Med Biol 356:293-302

4. Rivers J, Garrahy P, Robinson W, Murphy A (1987) Reversible cardiac dysfunction in hemochromatosis. Am Heart J 113:216-217

5. Anderson LJ, Holden S, Davis B, Presscott E, Charrier CC, Brunce NH, Firmin DN, Wonke B, Porter J, Walker JM, Pennell DJ (2001) Cardiovascular T2 star (T2*) magnetic resonance for the early diagnosis of myocardial iron overload. Eur Heart J 22:2171-2179

6. Tanner MA, Galanello R, Dessi C, Smith GC, Westwood MA, Agus A, Pibiri M, Nair SV, Walker JM, Pennell DJ (2008) Combined chelation therapy in thallassemia major for the treatment of severe myocardial siderosis with left ventricular dysfunction. $\mathrm{J}$ of Cardiovasc Magn Reson 10:12

7. Skulstad Davidsen E, Hervig T, Omvik P, Gerdts E (2009) Left ventricular long-axis function in treated haemochromatosis. Int J Cardiac Imaging. doi:10.1007/s10554008-9383-4

8. Rahko PS, Sclerni R, Uretsky BF (1986) Succesful reversal by chelation therapy of congestive cardiomyopathy due to iron overload. J Am Coll Cardiol 8:436

9. Jacobs A, Miller F, Worwood M, Beamisch R, Wardrop C (1972) Ferritin in the serum of normal subjects with iron deficiency and iron overload. Br Med J 206-211

10. Crosby WH (1976) Serum ferritin fails to indicate hemochromatosis: nothing gold cab stay. N Engl J Med 294:333-334

11. Brittenham GM, Badman DG (2003) Noninvasive measurement of iron: report of a NIDDK workshop. Blood 101:15-19

12. Hamdy AM (2007) Use of strain and tissue velocity imaging for early detection of regional myocardial dysfunction in patients with beta thallassemia. Eur J Echocardiogr 8:102-109 